Reprod. Nutr. Dévelop., 1983, 23 (5), 883-888.

\title{
Lesions of the hypothalamic region of the fetus and length of gestation in the guinea-pig
}

\author{
L. CALIGARIS $\left({ }^{*}\right)$, B. T. DONOVAN (1)
}

Department of Physiology, Institute of Psychiatry, De Crespigny Park, London SE5 8AF, U.K.

(*) Instituto de Investigacion Medica Mercedes y Martin Ferreyra, Casilla de Correo 389, 5000 Cordoba, Argentina.

Summary. A lesion was placed in the hypothalamic region of the brain of one fetus in each of 25 guinea-pigs on days 39-41 of pregnancy. Thirteen females were killed before delivery and the fetuses collected for histological examination of the brain. The young of twelve other females were killed immediately after delivery in order to determine the nature and extent of any brain damage, and the findings in both groups were compared with those recorded from a series of 23 similarly operated control animals in which lesions were not made. Delivery was not consistently advanced by the brain lesions and the results do not confirm those of an earlier study in which lesions of the hypothalamus of the fetus caused premature delivery.

\section{Introduction.}

The brains of the primate and sheep fetus can affect the timing of delivery (Boer, Swaab and Visser, 1979) whereas that of the rabbit appears to be of much less significance in influencing parturition (Heap et al., 1977). Little is known of the role played by the brain of the fetal guinea-pig. In a brief report, Donovan and Peddie (1973) noted that lesions placed in the midline basomedial region of the hypothalamus caused premature delivery. This was not related to the number of fetuses in the uterus, and the presence of more undisturbed than operated fetuses did not prevent premature delivery. Further, damage to extrahypothalamic structures, major stalk-median eminence lesions or destruction of the pituitary gland did not affect the timing of delivery. When delivery was advanced, it took place between 47 and 56 days, despite the placement of lesions at $\mathbf{4 0}$ days or at $\mathbf{5 0}$ days.

(1) Address for correspondence : B. T. Donovan, Department of Physiology, Institute of Psychiatry, De Crespigny Park, London SE5 8AF, U.K. 
The present work was begun in an effort to determine the mode of action of the lesions and involved detailed examination of the effect of hypothalamic lesions upon the timing of delivery. With a view to standardization, lesion placement was limited to a single individual among the cohort of fetuses in the uterus, and the lesions were made only between days 39-41. However, the results differed from those of the earlier study.

\section{Methods.}

Female guinea-pigs were housed in trays with a male and their oestrous cycles followed by daily examination of the vagina, with the collection of vaginal smears when the vagina was ofen. Pregnancies were timed from the day that sperm were detected in the vaginal smear.

Under pentobarbitone anaesthesia, a laparotomy was performed on day 39 , 40 or 41 of pregnancy and a lesion placed in the hypothalamus of one fetus in each of 25 pregnant females by inserting a platinum-tipped monopolar electrode through the uterine wall and the vault of the skull of the fetus, with the head of the most accessible fetus being grasped gently between finger and thumb. The electrode was directed in the midline through the cranium until the base of the skull was felt, then withdrawn approximately $0.5 \mathrm{~mm}$ and $3 \mathrm{~mA}$ D.C. passed for $30 \mathrm{sec}$, or $5 \mathrm{~mA} \mathrm{D.C}$. for $60 \mathrm{sec}$, with the brain electrode being anodal and a saline soaked pad applied to the uterus serving as the cathode. The puncture point at the uterine wall was ligatured to conserve amniotic fluid and to mark the operation site. This procedure was followed exactly in 23 blank operations, but direct current to make a lesion was not passed.

The animals were examined daily and, in the absence of premature delivery, some were killed on day 64,65 or 66 of pregnancy while others were left until delivery occurred naturally, when the newly born young were killed. After fixation, serial histological sections of the hypothalamic region of the brain were prepared and stained with Luxol blue and cresyl violet (Klüver and Barrera, 1953).

\section{Results.}

Histologically confirmed lesions were placed in the brain of one fetus in each of 25 guinea-pigs, and blank, control, operations were performed upon 23 others. The lack of brain damage in the latter animals was also confirmed histologically. Additionally, a lesion was placed in the brain of one fetus in nine other females where subsequent histological verification of the lesion site was not possible. Since in a number of cases the operated fetus could not be identified with certainty the brains of all of the young in that pregnancy were examined in serial sections. Litter size ranged between two and five, with 81 fetuses being carried by the 23 control females and 72 by the 25 guinea-pigs carrying a histologically studied lesioned fetus.

Laparotomy of the mother, and the insertion of an electrode into the brain of one fetus, did not cause premature delivery; that is delivery on or before day 64 of gestation. Eight females gave birth between days 65 and 69 , while pregnancy 
in 15 others continued undisturbed until they were killed on or after day 63 (table 1).

Three of twelve females carrying a lesioned fetus delivered on days 57, 62 and 62 ; parturition was not advanced in eight females and one female was found dead on day 61 . The lesions are described in Table 2, and no correlation between lesion site and location and the timing of delivery is evident. Death of the fetus was not associated with an early delivery (table 2).

Thirteen pregnant females were killed on or after day 64 of gestation, that is 24 days or more after a lesion had been placed in the brain of a fetus (table 1). Despite damage to a variety of diencephalic structures (table 3), gestation continued undisturbed. Most lesions involved the hypothalamus, although there was considerable variability in their size and shape.

Delivery occurred on days 42, 47, 50 (twice), 60, 61 and 64 (three times) in the nine additional females (not listed in table 1) operated upon on days 39, 40 or 41 and for which histological examination of the fetal heads was not possible. This was because in several instances early in the study the heads were dissected to check the accuracy of the placement of the lesions, and in other cases the newborns were partly eaten by cage companions of the mother.

\section{Discussion.}

Pregnancy in the guinea-pig is said to last about 67 or 68 days (Asdell, 1965), although in our experience the length of gestation is somewhat more variable and may extend between 66 and 70 days. Goy, Hoar and Young (1957) pointed out that the length of gestation varied inversely with litter size and, for a series of 116 genetically heterogenous animals, fell between 71 days for litters of one, and 67 days for litters of five and six, while Illingworth et al., (1974) illustrate a normal

TABLE 1

The timing of delivery or of autopsy after the insertion of an electrode into the brain of a fetus (control fetuses), or after the placement of a lesion (lesioned fetuses).

\begin{tabular}{|c|c|c|c|c|}
\hline & \multirow{2}{*}{$\begin{array}{l}\text { Number of } \\
\text { animals }\end{array}$} & \multicolumn{3}{|c|}{ Day of pregnancy at : } \\
\hline & & Operation & Delivery & Autopsy \\
\hline Control fetuses & $\begin{array}{r}2 \\
8 \\
12 \\
1\end{array}$ & $\begin{array}{l}39 \\
40 \\
40 \\
41\end{array}$ & $65,65,65,67,67,68,68,69$ & $\begin{array}{l}65,65 \\
63,64,64,65,65,65,65 \\
65,65,66,66,66 \\
65\end{array}$ \\
\hline Lesioned fetuses & $\begin{array}{r}2 \\
2 \\
8 \\
10 \\
\\
2 \\
1\end{array}$ & $\begin{array}{l}39 \\
39 \\
40 \\
\\
40 \\
\\
41 \\
41\end{array}$ & $\begin{array}{l}66,67 \\
57,62,62,66,67,68,68, \\
71^{*}\end{array}$ & $\begin{array}{l}65,70 \\
64,64,64,65,65,65,65, \\
65,66,66 \\
65\end{array}$ \\
\hline
\end{tabular}

* Found Dead 
TABLE 2

Effect of damage to the brain of a fetus upon the timing of delivery in the guinea-pig.

\begin{tabular}{|c|c|c|c|c|}
\hline \multicolumn{3}{|c|}{ Day of pregnancy at: } & \multirow{2}{*}{$\begin{array}{l}\text { Number of } \\
\text { fetuses }\end{array}$} & \multirow[b]{2}{*}{ Location of lesion in brain of fetus } \\
\hline Delivery & $\begin{array}{l}\text { Lesion } \\
\text { placement }\end{array}$ & $\begin{array}{l}\text { Lesioned fetus } \\
\text { Living (L) or Dead (D) }\end{array}$ & & \\
\hline 57 & 40 & D & 4 & $\begin{array}{l}\text { Optic chiasma and much of hypotha- } \\
\text { lamus destroyed. }\end{array}$ \\
\hline $61^{*}$ & 41 & $\mathrm{D}$ & 4 & $\begin{array}{l}\text { Lesion in septal area, dorsal to the } \\
\text { anterior commissure. }\end{array}$ \\
\hline 62 & 40 & L & 4 & $\begin{array}{l}\text { Unilateral lesion at caudal border of } \\
\text { hypothalamus. }\end{array}$ \\
\hline 62 & 40 & $\mathrm{D}$ & 2 & $\begin{array}{l}\text { Small cylindrical lesion in midline, } \\
\text { just caudal to pituitary stalk. }\end{array}$ \\
\hline 66 & 39 & $\mathrm{D}$ & 3 & Unilateral lesion in median eminence. \\
\hline 66 & 40 & L & 3 & $\begin{array}{l}\text { Extensive unilateral brain damage, } \\
\text { with destruction of optic chiasma } \\
\text { and part of anterior hypothalamus. }\end{array}$ \\
\hline 67 & 39 & L & 3 & $\begin{array}{l}\text { Large unilateral lesion in midbrain, } \\
\text { hypothalamus intact. }\end{array}$ \\
\hline 67 & 40 & $\mathbf{L}$ & 5 & $\begin{array}{l}\text { Lesion begins in preoptic area and } \\
\text { extends caudally to destroy optic } \\
\text { chiasma. }\end{array}$ \\
\hline 68 & 40 & $\mathrm{D}$ & 3 & $\begin{array}{l}\text { Large lesion in anterior hypotha- } \\
\text { lamus destroying optic chiasma. }\end{array}$ \\
\hline 68 & 40 & D & 2 & Large lesion in preoptic area. \\
\hline 69 & 41 & L & 3 & $\begin{array}{l}\text { Large unilateral lesion in preoptic } \\
\text { area, which extends caudally to } \\
\text { destroy one column of fornix and } \\
\text { the optic chiasma. }\end{array}$ \\
\hline $71^{*}$ & 40 & D & 4 & $\begin{array}{l}\text { Lesion in anterior basal median } \\
\text { eminence. }\end{array}$ \\
\hline
\end{tabular}

* Mother found dead.

distribution of 64 to 72 days. Accordingly, we have defined premature delivery as occurring on or before day 64 . Because of the difficulty of identifying an operated fetus after delivery, and to enable the contents of the uterus to be examined in situ, some of our animals were killed near the end of pregnancy. Earlier findings (Donovan and Peddie, 1973 ; Peddie, 1974) led us to anticipate that delivery would occur prematurely after lesion placement in the hypothalamus of the fetus between days 47 and 55 - an expectation that was not realised.

Whilst exposure of the uterus and the insertion of an electrode into the brain of the fetus does not appear to precipitate delivery, the placement of a lesion may have more adverse effects. Overall, premature delivery occurred in 12 of 34 females carrying a fetus in which a brain lesion was made, although the surgery and necessary manipulation of the uterus was exactly the same as in the control animals. Regrettably, histological verification of the size and location of the lesion was possible only in four (table 2), and it would be hazardous to base conclusions on the nine inadequately studied females delivering prematurely. 
TABLE 3

Location of lesions in the brains of guinea-pig fetuses killed before delivery.

\begin{tabular}{|c|c|c|c|c|}
\hline \multicolumn{2}{|c|}{ Day of pregnancy at : } & \multirow{2}{*}{$\underset{N^{\circ}}{\operatorname{Animal}}$} & \multirow{2}{*}{$\begin{array}{l}\text { Number of } \\
\text { fetuses }\end{array}$} & \multirow[b]{2}{*}{ Location of lesion in brain of fetus } \\
\hline $\begin{array}{l}\text { Lesion } \\
\text { placement }\end{array}$ & Autopsy & & & \\
\hline 39 & 65 & 107 & 2 & $\begin{array}{l}\text { Largely unilateral lesion in thalamus dorsal to } \\
\text { pituitary stalk with severe damage to dorsal } \\
\text { hippocampus. Marked cerebral cortical atrophy. }\end{array}$ \\
\hline 39 & 70 & 192 & 2 & $\begin{array}{l}\text { Midline lesion in preoptic area destroying optic } \\
\text { chiasma. }\end{array}$ \\
\hline 40 & 64 & 137 & 3 & $\begin{array}{l}\text { Lesion at caudal border of hypothalamus, } \\
\text { destroying half of mammillary body. }\end{array}$ \\
\hline 40 & 64 & 167 & 5 & $\begin{array}{l}\text { Large lesion in midline preoptic area ; consi- } \\
\text { derable damage to optic chiasma. }\end{array}$ \\
\hline 40 & 64 & 101 & 2 & $\begin{array}{l}\text { Midline lesion in anterior hypothalamus ; pitui- } \\
\text { tary stalk disrupted. }\end{array}$ \\
\hline 40 & 65 & 104 & 3 & Unilateral lesion in median eminence. \\
\hline 40 & 65 & 116 & 4 & $\begin{array}{l}\text { Basal lesion in midline anterior hypothalamus } \\
\text { destroying optic chiasma. Unilateral caudal } \\
\text { extension to ventro medial nucleus. }\end{array}$ \\
\hline 40 & 65 & 153 & 3 & Midline lesion destroying optic chiasma only. \\
\hline 40 & 65 & 157 & 3 & $\begin{array}{l}\text { Unilateral lesion in dorsal hippocampus. Hypo- } \\
\text { thalamus intact. }\end{array}$ \\
\hline 40 & 65 & 103 & 3 & $\begin{array}{l}\text { Optic chiasma destroyed, with unilateral exten- } \\
\text { sion involving one supraoptic nucleus. }\end{array}$ \\
\hline 40 & 66 & 142 & 3 & $\begin{array}{l}\text { Large lesion between optic chiasma and anterior } \\
\text { commissure. }\end{array}$ \\
\hline 40 & 66 & 59 & 3 & Basal lesion at caudal border of optic chiasma. \\
\hline 41 & 65 & 171 & 5 & $\begin{array}{l}\text { Substantial unilateral damage to hypothalamus } \\
\text { and part of hypophysis. }\end{array}$ \\
\hline
\end{tabular}

If attention is directed toward the association of midline mediobasal hypothalamic damage with premature delivery in the earlier series (Donovan and Peddie, 1973; Peddie, 1974) then lesions involving this area were present in six of the twelve animals represented in table 2, but only one of these delivered before day 66 . Similarly, comparable involvement was evident in six of the 13 fetuses in Table 3 that were maintained in utero. It may be argued that the decline in premature deliveries between the present and previous work is attributable to greater skill in surgery and animal care. However, the initial correlation between midline mediobasal hypothalamic damage and early delivery is unlikely to have arisen by chance, particularly as Peddie (1974) noted that gestation had been maintained up to day 60 in 17 pregnancies where fetal lesions were located at the periphery of the hypothalamus or in extra-hypothalamic structures. Because of the difficulty in applying precise stereotaxic methods to the guinea-pig fetus, some scatter in lesion locations was inevitable but expected to be helpful in defining the critical area. In the event, premature delivery was not as readily produced as anticipated.

The timing of lesion placement was limited to days $39-41$ in the present work 
in order that a large group of similarly treated animals could be accumulated. It was argued that the effects of brain damage produced around day 40 should persist, and that the short interval between lesion placement on day 50 and the expected early delivery precluded differentiation between any generalised adverse effect of surgery and the specific action of the lesion. It remains possible that delivery would be accelerated more uniformly by lesions made at 50 days.

In view of the lack of confirmation of the findings of the previous study, and in the absence of any satisfactory explanation for the discrepancy, discussion of the influence of the fetal brain in controlling delivery in this species is inappropriate. However, the intriguing possibility that damage to the hypothalamus of a single fetus can trigger the expulsion of the entire uterine contents remains. Unfortunately, the present direct approach to the matter has proved to be extremely laborious and unrewarding. Alternative methods would seem to be required.

Reçu en janvier 1983. Accepté en avril 1983

Acknowledgements. - This work was supported by a grant from the Nuffield Foundation when Laura Caligaris was a Fellow of the Consejo Nacional de Investigaciones Cientificas y Tecnicas of Argentina. Miss D. Allwood, Mrs M. Kibble and Mr S. Fleming provided able technical assistance.

Résumé. Lésions de l'hypothalamus foetal et déclenchement de la parturition chez le cobaye.

Chez 25 cobayes, au 39-41e jour de gestation, une lésion est pratiquée dans la région hypothalamique de l'un des fœetus. Treize femelles sont sacrifiées avant l'accouchement et le cerveau des fotus soumis à un examen histologique. Les jeunes des douze autres femelles sont sacrifiés immédiatement après la délivrance. La nature et l'étendue des lésions cérébrales sont déterminées. Les résultats obtenus dans ces deux groupes sont comparés avec ceux enregistrés chez 23 animaux servant de contrôle, chez lesquels aucune lésion n'a été pratiquée. Les lésions du cerveau ne provoquent pas systématiquement l'avortement et ce, en contradiction avec les résultats d'une précédente étude.

\section{References}

ASDELL S. A., 1965. Patterns of mammalian reproduction. 2nd Ed., Constable, London.

BOER K., SWAAB D. F., VISSER M., 1979. The fetal brain and parturition. Anim. Reprod. Sci., 2, 63-75.

DONOVAN B. T., PEDDIE M., 1973. Fœtal hypothalamic and pituitary lesions, the adrenal glands and abortion in the guinea-pig, 603-605. In Fœtal and neonatal physiology. Proc. Sir Joseph Barcroft Centenary Symp., Cambridge Univ. Press, London.

GOY R. W., HOAR R. M., YOUNG W. C., 1957. Length of gestation in the guinea-pig with data on the frequency and time of abortion and stillbirth. Anat. Rec., 128, 747-757.

HEAP R. B., GALIL A. K. A., HARRISON F. A., JENKIN G., PERRY J. S., 1977. Progesterone and oestrogen in pregnancy and parturition : comparative aspects and hierarchical control. Ciba Found. Symp., 47, 127-150. Elsevier, Amsterdam.

ILLINGWORTH D. V., CHALLIS J. R. G., ACKLAND N., BURTON A. M., HEAP R. B., PERRY J. S., 1974. Parturition in the guinea-pig; plasma levels of steroid hormones, steroid binding proteins and oxytocin, and the effect of corticosteroids, prostaglandins and adrenocorticotrophin. J. Endocr., 63, 557-570.

KLÜVER H., BARRERA E., 1953. A method for the combined staining of cells and fibres in the nervous system. J. Neuropath. exper. Neurol., 12, 400-403.

PEDDIE M., 1974. The development of neuroendocrine control of adrenal and gonadal function in the guinea pig. Ph. D. Thesis. Univ. London. 